\title{
Loss of biodiversity in a conservation unit of the Brazilian Atlantic Forest: the effect of introducing non-native fish species
}

\author{
E. N. Fragoso-Moura ${ }^{a *}$, L. T. Oporto ${ }^{b}$, P. M. Maia-Barbosa ${ }^{b}$ and F. A. R. Barbosa ${ }^{b}$ \\ aLaboratório de Dinâmica de Populações, Departamento de Hidrobiologia, Universidade Federal de São Carlos - UFSCar, \\ Rodovia Washington Luís, SP-310, Km 235, Monjolinho, CEP 13.565-905, São Carlos, SP, Brazil \\ 'Laboratório de Limnologia, Ecotoxicologia e Ecologia Aquática - LIMNEA, Instituto de Ciências Biológicas, \\ Universidade Federal de Minas Gerais - UFMG, Av. Antônio Carlos, 6627, ICB, bloco I3, \\ sala 163, Pampulha, CEP 31.270-901, Belo Horizonte, MG, Brazil \\ *e-mail: evelise@ufscar.br
}

Received: May 2, 2014 - Accepted: October 20, 2014 - Distributed: February 29, 2016

(With 4 figures)

\begin{abstract}
The introduction of species has become an important problem for biodiversity and natural ecosystem conservation. The lake system of the middle Rio Doce (MG, Brazil) comprises c. 200 lakes at various conservation states, of which 50 are located within the Rio Doce State Park (PERD). Previous studies had verified several of these lakes suffered non-native fishes introductions and the presence of these species needs for the implementation of actions aiming at not only their control but also the preservation of the native species. This study discusses the effects of non-native fish species in the largest conservation unit of Atlantic Forest in Minas Gerais, southeast of Brazil, using data from 1983 to 2010 distributed as follow: data prior to 2006 were obtained from previous studies, and data from September 2006 to July 2010 were obtained in Lake Carioca at four sampling stations using gillnets, seine nets and sieve. A total of 17 fish species was collected (2006-2010) of which five were introduced species. Among the small to medium size native species (30 to $2000 \mathrm{~mm}$ standard length) seven had disappeared, two are new records and one was recaptured. The non-native species Cichla kelberi (peacock bass) and Pygocentrus nattereri (red piranha) are within the most abundant captured species. Integrated with other actions, such as those preventing new introductions, a selective fishing schedule is proposed as an alternative approach to improve the conservation management actions and the local and regional biodiversity maintenance.
\end{abstract}

Keywords: fish fauna, biological invasion, Rio Doce basin, conservation management, local extinction.

\section{Perda de biodiversidade em uma unidade de conservação da Mata Atlântica brasileira: efeitos da introdução de espécies não nativas de peixes}

\begin{abstract}
Resumo
A introdução de espécies tornou-se um importante problema para a conservação da biodiversidade e dos ecossistemas naturais. O sistema de lagos do médio Rio Doce (MG, Brasil) compreende cerca de 200 lagos em vários estados de conservação, dos quais 50 estão localizados dentro do Parque Estadual do Rio Doce (PERD). Estudos anteriores demonstraram que vários desses lagos sofreram introduções de peixes não nativos. Este estudo discute os efeitos das espécies de peixes não nativos na maior unidade de conservação da Mata Atlântica em Minas Gerais, sudeste do Brasil, utilizando dados de 1983 até 2010, distribuídos da seguinte forma: dados de 1983 a 2005 obtidos de estudos realizados anteriormente, e dados de setembro de 2006 a julho de 2010 obtidos no lago Carioca, utilizando redes de emalhar, redes de arrasto e peneira. Um total de 17 espécies de peixes foi coletado (2006-2010), sendo cinco introduzidas. Dentre estas, Cichla kelberi (tucunaré) e Pygocentrus nattereri (piranha vermelha) estiveram dentre as mais abundantes. Entre as espécies nativas de pequeno a médio porte (30-2000 $\mathrm{mm}$ de comprimento padrão), duas foram novos registros e uma foi recapturada. O desaparecimento de sete destas espécies, registradas em estudos anteriores, e a baixa representatividade nas amostragens da maioria das espécies remanescentes, evidencia o alto impacto da invasão de peixes na comunidade estudada. Considerando a importância de ações de manejo de espécies não nativas visando à conservação e manutenção da biodiversidade local e regional, propõem-se a realização de pescas seletivas intensivas, juntamente com ações que previnam novas introduções, incluindo ações educativas junto às comunidades locais.
\end{abstract}

Palavras-chave: ictiofauna, invasão biológica, bacia do Rio Doce, manejo conservacionista, extinção local. 


\section{Introduction}

Brazil is well known for its impressive fauna and flora diversity with several endemic species. However, as other countries of the world it has suffered with negligent introduction of non-native species, mainly for agriculture and livestock production. Particularly in continental waters the introductions aiming at sport fishing, biological control and aquiculture are of paramount importance (Agostinho et al., 1994; Vitule et al., 2009; Pelicice et al., 2013). Although introductions are not new, only after 1990 studies aiming at non-native species became frequent (Speziale et al., 2012) and therefore, there are still many gaps about their impacts on the environment (Britton and Orsi, 2012; Vitule and Prodocimo, 2012).

In the middle Rio Doce lake system (Minas Gerais, Brazil) several introduced species have been recorded (Barbosa et al., 2013) and are in different phases of the invasion process (Blackburn et al., 2011). The gastropod Melanoides tuberculatus (Müller, 1774) and fish species such as Cichla kelberi Kullander \& Ferreira, 2006 (peacock bass) and Pygocentrus nattereri Kner, 1858 (red piranha) are spread in this lake system (De Marco Junior, 1999; Latini et al., 2004). Besides these species, other groups of animals were recently recorded in the region, such as the gastropod Achatina fulica Bowdich, 1822, the primate Callithrix penicillata (Geoffroy, 1812) (Barbosa et al., 2013) and representatives of the zooplankton community (Kellicottia bostoniensis (Rousselet, 1908) and Mesocyclops ogunnus Onabamiro, 1957) (Peixoto et al., 2010).

Particularly in the area of Rio Doce State Park (PERD), the largest and continuous remnant of Atlantic Forest in Minas Gerais (Brazil), the introduction of non-native fish species in several lakes caused considerable alterations in the natural communities, especially in the zooplankton one (Pinto-Coelho et al., 2008; Maia-Barbosa et al., 2010). Besides the impact on aquatic native species, species introduced in an area may affect other groups of the local biota, causing negative effects on insects and piscivorous birds and simplifying the food web (Zaret and Paine, 1973; Epanchin et al., 2010; Ricciardi and MacIsaac, 2011).

Among the 15 hydrographic basins of Minas Gerais the Rio Doce basin is the fourth in fish species richness (64 species), most of them endemic (Drummond et al., 2005). Previous studies in the 1950's reported the occurrence of 35 fish species in this basin, including introduced species such as Salminus sp. (freshwater dourado), Lophiosilurus alexandri Steindachner, 1876 (Pacamã), C. kelberi and P. nattereri (Godinho, 1996). In the 1980's, Sunaga and Verani (1991) recorded 27 species for four lakes (Dom Helvécio, Carioca, Amarela and Jacaré), including the non-natives C. kelberi, P. nattereri and Astronotus ocellatus (Agassiz, 1831). In the 1990 's, after 10 years of the detection of the introduced species in lakes Dom Helvécio and Carioca within PERD and lake Jacaré at the surroundings (Sunaga and Verani, 1991), Godinho (1996) verified a reduction of $50 \%$ of the native species.

Latini et al. (2004) assessing the fish fauna of 56 lakes within PERD and surroundings recorded introduced species in 40 of them, among which 30 had P. nattereri and C. kelberi and only three lakes within PERD and 13 lakes at the surroundings did not have introduced species. Furthermore, in this assessment they also captured four new introduced species: Hoplosternum littorale (Hancock, 1828) (armored catfish), Colossoma macropomum (Cuvier, 1816) (tambaqui), Oreochromis niloticus (Linnaeus, 1758) (Nile tilapia) and Clarias gariepinus (Burchell, 1822) (African catfish). Moreover, Vasconcellos et al. (2005) collected 31 species in 22 sampled lakes, with the first record of the native Callichthys callichthys (Linnaeus, 1758) (armored catfish) for Lake Carioca, besides H. littorale and C. gariepinus.

The history of introduction and dispersion of these species in the middle Rio Doce lake system is probably related to anthropogenic actions and occasional communication of the lakes with tributaries of Rio Doce (Godinho et al., 1994). In the case of $C$. kelberi and P. nattereri, characteristics such as piscivorous feeding habits and parental care contribute to their population expansion and consequent impact on native fish fauna.

The present study aimed the characterization of the present composition of Lake Carioca's fish fauna and the assessment of its alterations with time through the comparison of data from this study with data registered in the literature, considering the effects of non-native fish on the native fish fauna.

\section{Material and Methods}

\subsection{Study area}

The Rio Doce State Park (Figure 1), the largest remnant of Atlantic Forest in Minas Gerais State and a Ramsar site since March 2010 (http://www.ramsar.org/), is located in the eastern region of Minas Gerais, at the middle Rio Doce

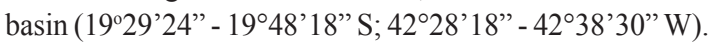
The local climate is hot tropical and semi-humid with well defined rainy (September/October-March) and dry (May-August) seasons. The main anthropogenic impacts come from extensive agriculture and cattle rising, mining, metallurgy, and cultivation of Eucalyptus spp. (Barbosa and Moreno, 2002).

Lake Carioca, located in the south region of PERD in the coordinates $19^{\circ} 45^{\prime} 26.3^{\prime \prime} \mathrm{S}-42^{\circ} 37^{\prime} 62^{\prime \prime} \mathrm{W}$ was chosen for this study due to the existing scientific knowledge on this environment, its small size and accessibility. It is a mesotrophic lake, according to Salas and Martino's model (Salas and Martino, 1991), with water temperature ranging between $24.3^{\circ} \mathrm{C}$ and $33.4^{\circ} \mathrm{C}$ (Brito and Maia-Barbosa, 2009). It is surrounded by dense vegetation, has a maximum depth of $11.8 \mathrm{~m}$, round shape and area of 14.1 ha (Bezerra-Neto et al., 2010). 


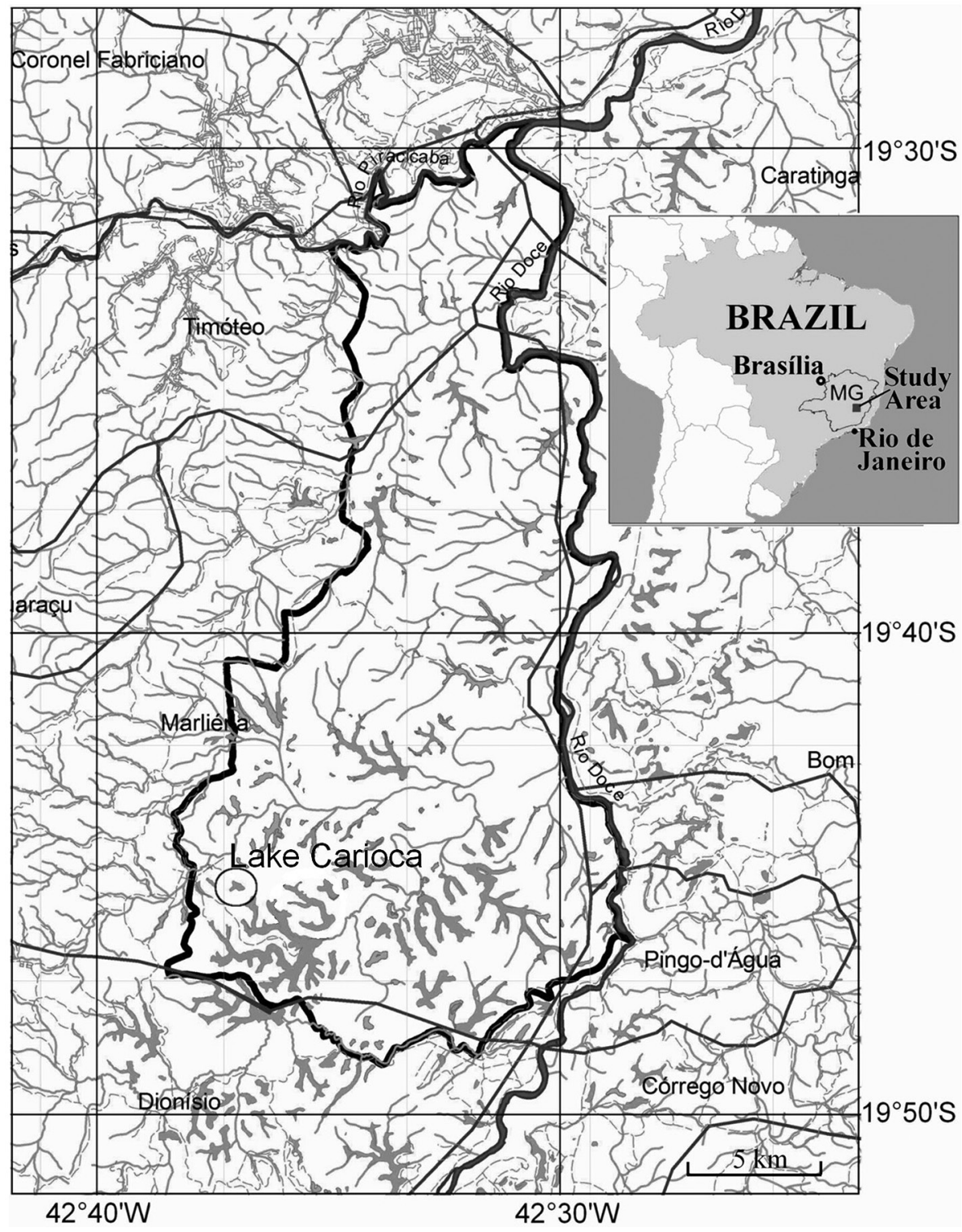

Figure 1. Map of the study area with location of Lake Carioca, Rio Doce State Park (PERD)/MG. Adapted from Maillard et al. (2012).

The samplings were done in four representative habitats of the littoral zone mainly characterized by the alternating regions of macrophytes and forest edges.

\subsection{Samplings}

The samples were collected in two phases with standardized effort for each: i) characterization of the lake's fish fauna with bi-monthly samplings between September 2006 and September 2007 and ii) after a period of methodological adjustments in 2008, sampling aiming at the implementation of an experimental management for introduced species control, conducted between March 2009 and July 2010, with samples concentrated in the rainy season in order to guaranteeing the capture of juveniles of the fish species.
In the first phase, samplings were performed with sets of $10 \mathrm{~m}$ long gillnets and meshes of 1.5 until $6.0 \mathrm{~cm}$ disposed perpendicular to the lake shore, besides fish traps with bait, and 24 hours fishing effort, checked at 8 hours interval, and exploratory samples with sieves and seine nets. During 2008, three samplings were performed with variations of the sampling points, fishing gear used and fishing effort applied. Besides the fishing gear used in the other phases, trawls were done at the limnetic region (30 $\mathrm{m}$ long, $1 \mathrm{~m}$ high and meshes of 1.5, 2.0, and $3.0 \mathrm{~cm}$ between adjacent knots) and long-line with treble fish hooks and single type fish hooks with natural bait (liver and fish pieces) and cast net (1.5 cm mesh) were used at the littoral zone. 
From 2009 net sets were disposed perpendicular and parallel to the lake shore doubling the sampling effort of the previous period, besides daytime and nocturnal samples with seine nets (meshes 0.25 and $1.2 \mathrm{~cm}$ ) and sieve $(0.25 \mathrm{~cm} \mathrm{mesh})$, performed systematically with a duration of 30 minutes at one of the macrophytes regions. Complementarily, we also used $40 \mathrm{~m}$ long gillnets with meshes of 3.0 and $4.0 \mathrm{~cm}$, used in "beating fish" in macrophyte's regions and meshes of 5.0 and $6.0 \mathrm{~cm}$ placed next to the substrate in deep places of the forest edge. Finally, exploratory samples were collected with fishing rod and reel (natural and artificial bait), sieve, hand and seine nets in different regions of the lake.

After the collection, samples were identified (date, time, fishing equipment), placed in plastic bags and frozen afterwards. Data on the presence and absence of the present study and the literature (Sunaga and Verani, 1991; Godinho et al., 1994; Latini et al., 2004; Vasconcellos et al., 2005; Pinto-Coelho et al., 2008) were used to verify changes in temporal composition of fish species, as well as a search in the Museum of Zoology, University of São Paulo. We emphasize that the probabilities of occurrence are not constant in time, since the collection efforts were different between studies. Furthermore, we are aware that this limitation restricts generalizations about the fish community but provides support to conclude in some specific cases. Sampling sufficiency was verified by a species accumulation curve using samples performed between 2006 and 2010 .

Voucher specimens were deposited in the collections of the Federal University of Minas Gerais (MHN-UFMG 1406 to 1418) and the Zoology Museum of the University of São Paulo (MZUSP 106770, 106771, 107327 to 107340 , 109029 and 115385).

\section{Results}

A total of 17 species was collected between 2006-2010, representing four orders and nine families, of which Characidae and Cichlidae are the most representative in Lake Carioca. Among these species, 12 are natives (Table 1). The largest species loss occurred in the Characiformes (4 species) followed by Perciformes ( 2 species) and Siluriformes (1 species), with three species of the Characidae, two of the Cichlidae and one of the Curimatidae and Loricariidae. The addition of non-native species occurred in the following Orders: Siluriformes (2), Perciformes (2) and Characiformes (1), respectively in the families Callichthyidae (1) and Clariidae (1), Cichlidae (2) and Characidae (1) (Figure 2).

Among the 24 species recorded in Lake Carioca since 1983, 19 are native and five are non-native ones. Comparing data obtained in this study with data from previous studies (1983-2005) allows verifying an increase of the total number of species in this lake. However, considering the data from the 1980's and C. kelberi as the only non-native species recorded in that decade, it can be concluded that there was a vertiginous and abrupt decrease of the number of native species. Moreover, seven small native species were not captured since 1992, indicating they became rare species or locally extinct as shown in Table 2.

A comparison of species richness recorded in Lake Carioca since 1983 (Table 2) showed that small species were the first affected. For instance, Cyphocharax gilbert (Quoy \& Gaimard, 1824) (saguiru) and Moenkhausia doceana (Steindachner, 1877) (lambari) were not captured shortly after the detection of $C$. kelberi. The same happened to another species of Characidae collected only in 1985, deposited in the Zoology Museum of the University of São Paulo (MZUSP) and not yet described. However, from 1992 there was an increase in the number of species in the lake, mainly due to the presence of non-native species and more recently to the new records of medium size native species namely Gymnotus sp. (banded knifefish) and Trachelyopterus striatulus (singing catfish) (Table 2). Moreover, the increase of sampling effort in the last four years allowed to record two new small size native species

Table 1. List of the fish species collected in Lake Carioca, Rio Doce State Park - MG, between September 2006 and July 2010.

\begin{tabular}{l}
$\quad$ Species \\
\hline Order - CHARACIFORMES \\
Family - ERYTHRINIDAE \\
Hoplerythrinus unitaeniatus (Spix \& Agassiz, 1829) \\
Hoplias gr. malabaricus (Bloch, 1794) \\
Family - ANOSTOMIDAE \\
Leporinus cf. steindachneri Eigenmann, 1907 \\
Family - CHARACIDAE \\
Astyanax aff. bimaculatus (Linnaeus, 1758) \\
Astyanax sp. \\
Brycon sp. \\
Hasemania sp. \\
Knodus moenkhausii (Eigenmann \& Kennedy, 1903) \\
Pygocentrus nattereri Kner, 1858* \\
Order - GYMNOTIFORMES \\
Family - GYMNOTIDAE \\
Gymnotus sp. \\
Order - SILURIFORMES \\
Family - CLARIIDAE \\
Clarias gariepinus (Burchell, 1822)* \\
Family - HEPTAPTERIDAE \\
Rhamdia quelen (Quoy \& Gaimard, 1824) \\
Family - AUCHENIPTERIDAE \\
Trachelyopterus striatulus (Steindachner, 1877) \\
Family - CALLICHTHYIDAE \\
Callichthys callichthys (Linnaeus, 1758) \\
Hoplosternum littorale (Hancock, 1828)* \\
Order - PERCIFORMES \\
Family - CICHLIDAE \\
Astronotus cf.ocellatus (Agassiz, 1831)* \\
Cichla kelberi Kullander \& Ferreira, 2006* \\
\hline
\end{tabular}



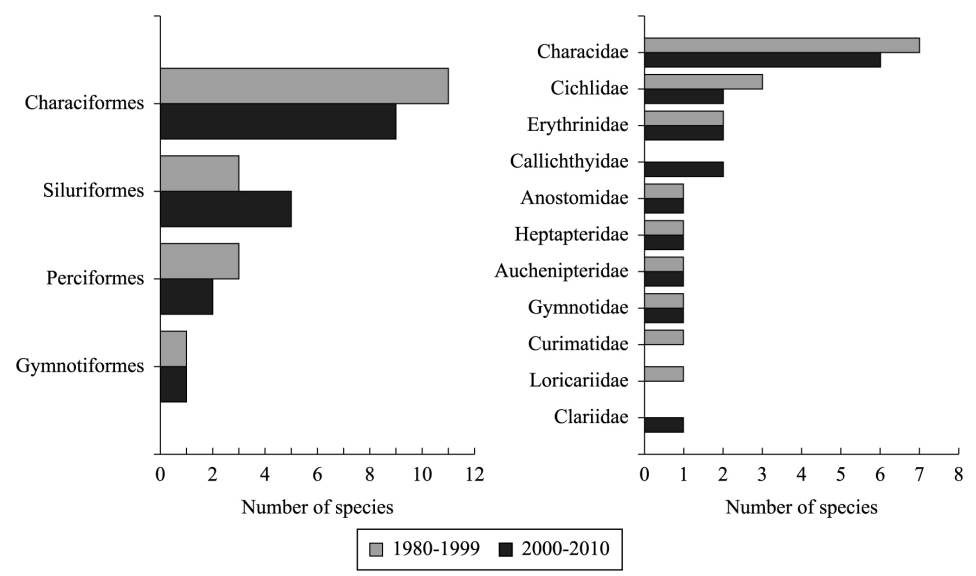

Figure 2. Orders and families of the fish species recorded in Lake Carioca (Rio Doce State Park/MG) along the three decades of studies

Table 2. Historical composition of the species in Lake Carioca based on the literature, collections and the present study. Modified of Sunaga and Verani (1991) and Godinho et al. (1994).

\begin{tabular}{|c|c|c|c|c|c|c|c|c|c|}
\hline Species/ Samplings & 1983 & 1985 & 1987 & 1992 & 2002 & $\begin{array}{c}2002- \\
2003\end{array}$ & $\begin{array}{c}2004- \\
2005\end{array}$ & $\begin{array}{l}2006- \\
2008\end{array}$ & $\begin{array}{c}2009 \\
2010\end{array}$ \\
\hline \multicolumn{10}{|l|}{ Native } \\
\hline Hoplias gr. malabaricus & & & & & -- & & & & \\
\hline Brycon sp. & & & & & -- & & & & \\
\hline Leporinus cf. steindachneri & & & & & -- & & & & \\
\hline Rhamdia quelen & & & & & -- & & & & \\
\hline Astyanax aff. bimaculatus & & & & & -- & & & & \\
\hline Geophagus brasiliensis & & & & & -- & & & & \\
\hline Moenkhausia doceana & & & & & -- & & & & \\
\hline Oligosarcus solitarius & & & & & -- & & & & \\
\hline Cyphocharax gilbert & & & & & -- & & & & \\
\hline Characidae gen. n. sp. n.* & & $* * *$ & & & -- & & & & \\
\hline Loricariidae gen. sp. & & & & & -- & & & & \\
\hline Australoheros sp. & & & & & -- & & & & \\
\hline Astyanax sp. * & & $* *$ & & & -- & & & & \\
\hline Hoplerythrinus unitaeniatus & & & & & -- & & & & \\
\hline Gymnotus sp. & & & & & -- & & & & \\
\hline Trachelyopterus striatulus & & & & & -- & & & & \\
\hline Callichthys callichthys & & & & & -- & $* * * *$ & & & \\
\hline Knodus moenkhausii \# & & & & & -- & & & & \\
\hline Hasemania sp. \# & & & & & -- & & & & \\
\hline \multicolumn{10}{|l|}{ Introduced } \\
\hline \multicolumn{10}{|l|}{ Cichla kelberi } \\
\hline \multicolumn{10}{|l|}{ Pygocentrus nattereri } \\
\hline \multicolumn{10}{|l|}{ Hoplosternum littorale } \\
\hline \multicolumn{10}{|l|}{ Clarias gariepinus } \\
\hline \multicolumn{10}{|l|}{ Astronotus cf. ocellatus } \\
\hline Total - Native & 11 & 11 & 7 & 8 & -- & 8 & 3 & 10 & 10 \\
\hline Total - Introduced & 0 & 1 & 1 & 2 & 4 & 6 & 3 & 4 & 5 \\
\hline Total Species & 11 & 12 & 8 & 10 & -- & 14 & 6 & 14 & 15 \\
\hline References & \multicolumn{3}{|c|}{$\begin{array}{l}\text { Sunaga and Verani } \\
\qquad(1991)\end{array}$} & $\begin{array}{l}\text { Godinho } \\
\text { et al. } \\
\text { (1994) }\end{array}$ & $\begin{array}{l}\text { Latini } \\
\text { et al. } \\
(2004)\end{array}$ & $\begin{array}{c}\text { Vasconcellos } \\
\text { et al. } \\
(2005)\end{array}$ & $\begin{array}{l}\text { Pinto- } \\
\text { Coelho } \\
\text { et al. } \\
(2008)\end{array}$ & Presen & t Study \\
\hline
\end{tabular}

shaded $=$ presence; blank $=$ absence; -- = not informed. $*$ Based on the lots examined from the MZUSP collection and personal communication of J.R.Verani. Species named Astyanax cf. fasciatus ** and Oligosarcus sp. *** in Sunaga and Verani (1991). $* * * *$ considered as introduced species; \# = new record. 


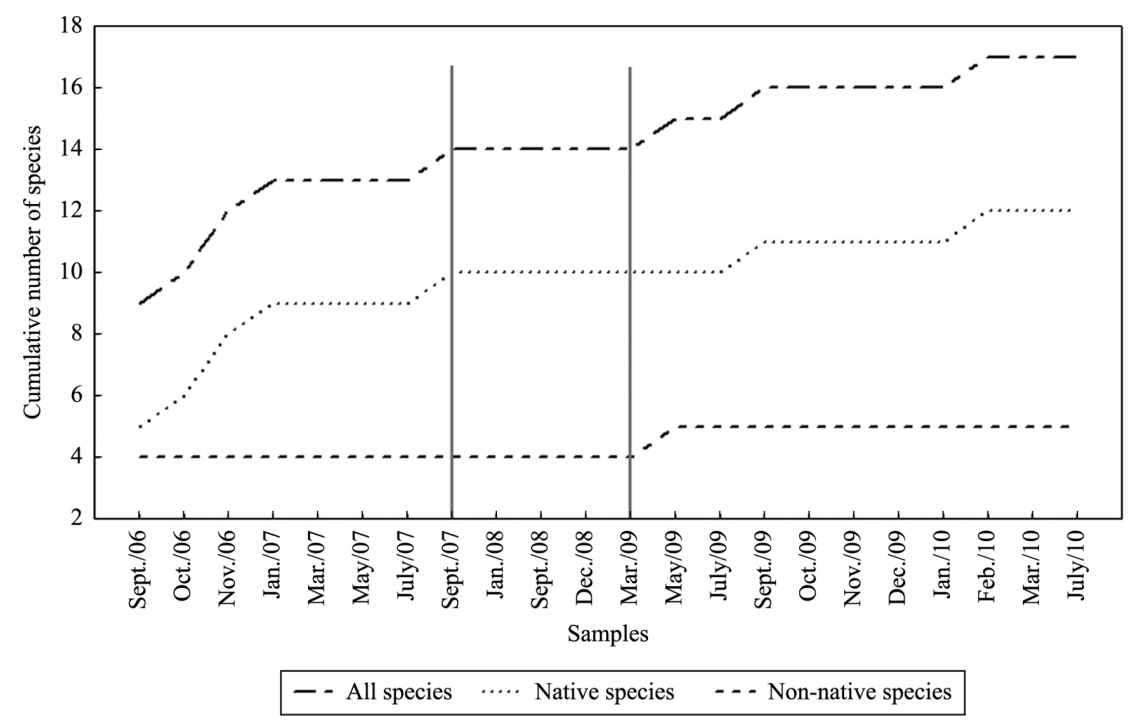

Figure 3. Accumulation curves of species collected in Lake Carioca between 2006 and 2010, evidencing native and introduced species. The vertical lines indicate the beginning of a new sampling effort

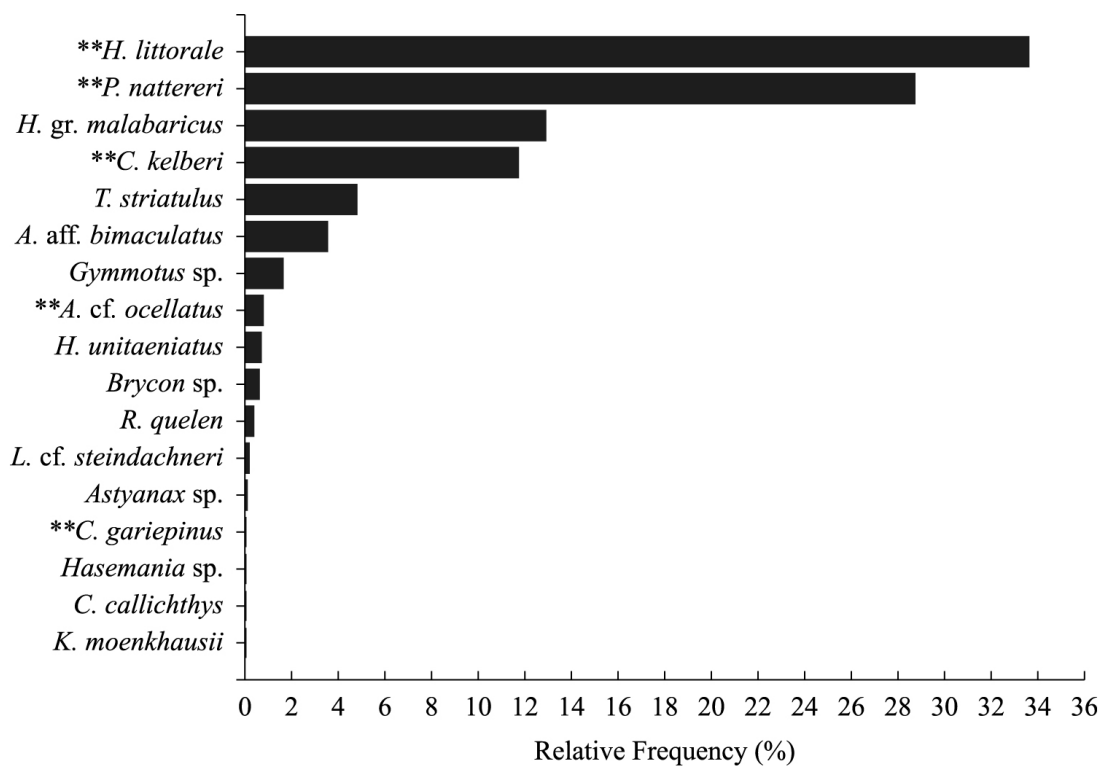

Figure 4. Relative abundance of the species collected in Lake Carioca between 2006 and 2010. **non-native species.

(Hasemania sp. and Knodus moenkhausii) (Table 2), together with another one recaptured since it's last record in 1985 (Astyanax sp.) (Table 2) and a non-native species previously recorded (Clarias gariepinus) (Table 2) thus increasing the species list of Lake Carioca (Figure 3), although the occurrence of native species declined.

Cichla kelberi and P. nattereri are among the five most abundant species in the lake, being captured with all used fishing equipment (Figure 4). Of the total captured 24.6\% were native species, with Hoplias gr. malabaricus, the most abundant native species, representing approximately 50\% of the total captured native specimens.

\section{Discussion}

Amongst the four orders present in the Carioca lake - Gymnotiformes, Perciformes, Characiformes and Siluriformes - the last two concentrate $81.2 \%$ of the identified species, corroborating the indication that these orders are the ones with the highest species' richness in the neotropical region (Lowe-McConnell, 1999). Two of the largest fish families known are also represented here: Characidae and Cichlidae.

The sampling records for Lake Carioca date back for approximately three decades demonstrating the drastic 
changes in communities affected by non-native fishes, several of them invasive species (Latini and Petrere-Junior, 2004). The present data indicate considerable changes on species composition, especially loss of small sized species, mainly Characidae, addition of non-native species ( $P$. nattereri), replacement on Cichlidae of two native species by the non-natives $C$. kelberi and $A$. cf. ocellatus and presence of the non-native $C$. gariepinus. Furthermore, the new records and recapture of small size native species (Hasemania sp., K. moenkhausii and Astyanax sp.) may have occurred because the previous samplings did not collected these species due to the fishing equipment used and also to its low abundance, demonstrating the importance of the fishing equipment selection and the sampling effort to be applied.

The endurance of these species in an environment with high predation pressure not only by the exotic piscivorous species but also by the native $H$. gr. malabaricus (trahira) is associated to its small size and to the fact that they inhabit vegetated shallow regions which makes it more difficult for most large size predators to reach. However, the low abundance for the small sized species and the high one for predator species suggest that the first ones are threatened.

Information about characteristics of the processes and mechanisms of species introductions is difficult to obtain and therefore they are normally accompanied by a considerable degree of inaccuracy and uncertainty. Based on the available literature there are 27 non-native species in Rio Doce basin (Vieira, 2009-2010) seven occurs in lakes of the middle Rio Doce, five of which have been already recorded in la kes within the Rio Doce State Park (Latini et al., 2004).

Intentional introductions are related to recreational fishing for local population and, more recently, to the increase of fish farms and net cages activities in the region. The fact that fish cultivation is one of the main sources of dispersion of non-native species is well known (Casal, 2006; Pelicice et al., 2013). In the middle Rio Doce region it was responsible for the appearance of $C$. gariepinus and tilapias, among other species (Latini et al., 2004). On the other hand, the origin of $H$. littorale and $A$. cf. ocellatus in the region is uncertain and, according to Latini et al. (2004) it was probably due to the use of the species as bait (H. littorale) and as aquarium pets (A. cf. ocellatus), respectively. The first record of $H$. littorale was in 2002 in 10 lakes of the region, including two of them within the Rio Doce State Park (Latini et al., 2004; Vasconcellos et al., 2005). Astronotus cf. ocellatus was captured in 1987 in Lake Amarela (surroundings of PERD) and in 1992 it was recorded in Lake Dom Helvécio (inside PERD) with consequences from its introduction still to be known (Godinho, 1996).

Differently, for C. kelberi and P. nattereri there are better documented introduction records. According to Godinho et al. (1994) both were introduced in the middle Rio Doce in the 1960's in the surrounding lakes of the Rio Doce State Park and the important impact on native species is mainly attributed to these two species (Godinho,
1996). An example of this impact on local biodiversity is the disappearance of Oligosarcus solitarius Menezes, 1987, an endemic species of the region, in lakes where the presence of $C$. kelberi and $P$. nattereri was identified (Vieira, 1994). Moreover, other small sized species, major food sources for piscivorous species, like M. doceana, Geophagus brasiliensis (Quoy \& Gaimard, 1824) and Australoheros sp., were also directly affected and not recorded in Lake Carioca since 1992 to the present date.

Considering that this study have used the largest fishing effort and greater diversity of fishing gear as compared to all previous studies and that seven species collected in the past have not been sampled in recent studies, one can conclude on the possibility of their local extinction.

The competition for resources such as shelter, feeding and nesting places, threatens all species of fishes, and predation impacts affect adults and offspring. Healthy large size specimens such as Brycon sp. (piabanha) threatened of extinction in Rio Doce basin and Leporinus cf. steindachneri (piau) may escape predation. However, their offspring will not have the same chance and thus considerably reducing their chances of survival in the lake in the medium to long terms.

As a result of the disappearance of these species, most of them known as foraging fishes, severe alterations on planktonic community composition and structure in Lake Dom Helvécio have been evidenced by MaiaBarbosa et al. (2010), calling attention for the dominance of Chaoborus larvae as top predators of plankton food-chain (Pinto-Coelho et al., 2008, Barbosa et al., 2013).

Among the possible mechanisms used by native species to resist invasion impacts their diet's change should be highlighted. Hoplias gr. malabaricus, a native piscivorous species, changes its diet to shrimps in some lakes inside and surrounding the Rio Doce State Park with C. kelberi and $P$. nattereri (Pompeu and Godinho, 2001).

Another considerable and worrying change in Lake Carioca was the expansion of $H$. littorale, becoming the predominant species in this environment. The ecological alterations in the fish community due to its population expansion is not known yet, since it is not a predator species but can compete for common resources with other species such as spawning areas. This species is well adapted to the environment presenting biological adaptations such as obligated air breather, parental care and floating foam nest building and guarding by males (Reis, 2003; Mol, 1996; Reis, 1998). Considering that diet studies performed at the wetlands of the upper Paraná River basin, its native area, indicate high predation of microcrustaceans, chironomids and nematodes (Hahn et al., 1997), it is possible that its higher impact is on zooplankton and zoobenthos communities, disrupting the food web and consequently the ecosystem functioning. On the other hand, it can also be an alternative resource to the lake's piscivorous species since it was identified as a food item of P. nattereri (Santos, 2008) and of $C$. kelberi (PELD/UFMG Report, non-published data) in Lake Carioca. 
Considering the complexity and uncertainties of the above mentioned, future studies focusing on conservation strategies and mitigation of impacts caused by the introduction of species in the middle Rio Doce lake system are a top priority. The implementation of preventive management actions in order to impede the access of introduced species to other lakes is particularly important and can be done by an effective access control of fishermen to these environments, together with an effective management program including the increase of awareness of the risks and consequences of biologic introductions.

The introduction of non-native species is currently the most important ecological problem at the Rio Doce State Park and its control is one of the greatest challenges of basic and applied research initiative developed in the region. The presence of non-native species is a constant threat to native species, with a potential risk of exclusion and extinction at local and regional scales as demonstrated in this study.

Other local extinctions may probably be already happening considering other non-native species identified in lakes of Rio Doce State Park, such as the rotifer Kellicotia bostoniensis and the copepod Mesocyclops ogunnus (Peixoto et al., 2010). The problem is even more important if we consider the invasion potential of other species already identified in the region, such as the plant Leucaena leucocephala (Lam.) de Wit and the mollusk Achatina fulica (Barbosa et al., 2013).

In order to guaranteeing and preserve local and regional biodiversity the implementation of management actions both at Rio Doce State Park and its surroundings is urgent, aiming at controlling the introduced species. Specifically for fishes, selective fishing and selective harvest (Britton et al., 2011) should be prioritized as examples of management techniques to be implemented in order to provide an effective control of introduced species. The selective fishing of non-native species as a management action involving the participation of fishermen visiting the Rio Doce State Park has been stimulated at Lake Dom Helvécio, the largest and only lake in the area open to sport fishing of only non-native species. Although there is not yet an effective control of this particular fishing initiative fishermen have reported a gradual increase of native species along the last three years.

For three consecutive years (2006-2008) non-native species were systematically removed from lake Carioca using distinct fish gears and in 2009 an experimental project of selective removal of these species was conducted. The use of this approach demonstrated its potential to decrease introduced species density with intensive effort as well as to increase native species diversity.

Studies on the biology and behavior of these species such as feeding, shelter and nesting places as well as dispersal forms are still required to allow successful measures to preserve fish species in the medium to long term. Moreover, without appropriate conservation measures species extinction is inevitable as the loss of biodiversity and growing impacts on evolutionary processes take place in these unique environments.

It must be pointed out that all these actions must be taken in association with environmental education activities capable of promoting awareness of the general public who must be an effective partner of the conservation effort.

\section{Acknowledgements}

To the National Research Council - CNPq (Proc. 520031/89-9) and to FAPEMIG (Proc. CRA-APQ-01601-08) for financial supports. To the Minas Gerais State Forest Institute (IEF-MG) for the scientific research permission and logistic support at the Rio Doce State Park. To the researchers Mauro Luís Triques (ICB-UFMG), Osvaldo T. Oyakawa (Zoology Museum/USP), Francisco Langeani Neto (UNESP) and Alexandre K. de Oliveira (UFSCar) for the identification of the fish species.

\section{References}

AGOSTINHO, A.A., JÚLIO-JUNIOR, H.F. and PETRERE-JR, M., 1994. Itaipu Reservoir (Brazil): impacts of the impoundment on the fish fauna and fisheries. In: I.G. COWX, ed. Rehabilitation offreshwater fisheries. London: Fishing News Books. pp. 171-184.

BARBOSA, F.A.R., LOVATO, M.A., NASCIMENTO, A.M.A., MAIA-BARBOSA, P.M., MONTE-MÓR, R.L., PAGLIA, A. and STEHMANN, J.R., 2013. Dinâmica biológica e conservação da biodiversidade da Mata Atlântica do médio Rio Doce, MG (PELD/ UFMG). In: M. TABARELLI, C.F.D. ROCHA, H.P. ROMANOWSKI, O. ROCHA and L.D. LACERDA, eds. PELDCNPq: dez anos do Programa de Pesquisas Ecológicas de Longa Duração do Brasil: achados, lições e perspectivas. Recife: Editora Universitária da UFPE. pp. 115-145.

BARBOSA, F.A.R. and MORENO, P., 2002. Mata Atlântica e sistema Lacustre do Rio Doce Site 4. In: U. SEELIGER, C. CORDAZZO and F.A.R. BARBOSA, eds. Os sites e o Programa Brasileiro de Pesquisas Ecológicas de Longa Duração. Belo Horizonte: Fundação Universidade Federal do Rio Grande do Sul. pp. 69-81.

BLACKBURN, T.M., PYŠEK, P., BACHER, S., CARLTON, J.T., DUNCAN, R.P., JAROŠÍK, V., WILSON, J.R. and RICHARDSON, D.M., 2011. A proposed unified framework for biological invasions. Trends in Ecology \& Evolution, vol. 26, no. 7, pp. 333-339. http:// dx.doi.org/10.1016/j.tree.2011.03.023. PMid:21601306.

BEZERRA-NETO, J.F., BRIGUENTI, L.S. and PINTO-COELHO, R.M., 2010. A new morphometric study of Carioca Lake, Parque Estadual do Rio Doce (PERD), Minas Gerais State, Brazil. Acta Scientiarum. Biological Science, vol. 32, no. 1, pp. 49-54.

BRITO, S.L. and MAIA-BARBOSA, P.M., 2009. Differences in body size of Thermocyclops minutus (Lowndes, 1934) in two tropical lakes. Acta Limnologica Brasiliensia, vol. 21, no. 4, pp. 409-414.

BRITTON, J.R., GOZLAN, R.E. and COPP, G.H., 2011. Managing non-native fish in the environment. Fish and Fisheries, vol. 12, no. 3, pp. 256-274. http://dx.doi.org/10.1111/j.1467-2979.2010.00390.x.

BRITTON, J.R. and ORSI, M.L., 2012. Nonnative fish in aquaculture and sport fishing in Brazil: economic benefits versus risks to fish diversity in the upper River Paraná Basin. Reviews 
in Fish Biology and Fisheries, vol. 22, no. 3, pp. 555-565. http:// dx.doi.org/10.1007/s11160-012-9254-x.

CASAL, C.M.V., 2006. Global documentation of fish introductions: the Growing Crisis and Recommendation for Action. Biological Invasions, vol. 8, no. 1, pp. 3-11. http://dx.doi.org/10.1007/ s10530-005-0231-3.

DE MARCO JUNIOR, P., 1999. Invasion by the introduced aquatic snail Melanoides tuberculatus (Müller, 1774) (Gastropoda: prosobranchia: thiaridae) of the Rio Doce State Park, Minas Gerais, Brazil. Studies on Neotropical Fauna and Environment, vol. 34, pp. 186-189. http://dx.doi.org/10.1076/snfe.34.3.186.8908.

DRUMMOND, G.M., MARTINS, C.S., MACHADO, A.B.M., SEBAIO, F.A. and ANTONINI, Y., 2005. Biodiversidade em Minas Gerais: um atlas para a sua conservação. Belo Horizonte: Fundação Biodiversitas. 222 p

EPANCHIN, P.N., KNAPP, R.A. and LAWLER, S.P., 2010. Nonnative trout impact an alpine-nesting bird by altering aquaticinsect subsidies. Ecology, vol. 91, no. 8, pp. 2406-2415. http:// dx.doi.org/10.1890/09-1974.1. PMid:20836462.

GODINHO, A.L., 1996. Peixes do Parque Estadual do Rio Doce. Belo Horizonte: IEF/UFMG.

GODINHO, A.L., FONSECA, M.T. and ARAÚJO, L.M., 1994. The ecology of predator fish introductions: the case of Rio Doce Valley Lakes. In: R.M. PINTO-COELHO, A. GIANI and E. VON SPERLING, eds. Ecology and human impact on lakes and reservoirs in Minas Gerais. Belo Horizonte: SEGRAC. pp. 77-83.

HAHN, N.S., ALMEIDA, V.L.L. and LUZ, K.D.G., 1997. Alimentação e ciclo alimentar diário de Hoplosternum littorale (Hancock) (Siluriformes, Callichthydae) nas lagoas Guaraná e Patos da planície do Alto Rio Paraná, Brasil. Revista Brasileira de Zoologia, vol. 14, no. 1, pp. 57-64. http://dx.doi.org/10.1590/ S0101-81751997000100005.

LATINI, A.O. and PETRERE JUNIOR, M., 2004. Reduction of a native fish fauna by alien species: an example from Brazilian freshwater tropical lakes. Fisheries Management and Ecology, vol. 11 , no. 2 , pp. 71-79. http://dx.doi.org/10.1046/j.13652400.2003.00372.x

LATINI, A.O., LIMA-JUNIOR, D.P., GIACOMINI, H.C., LATINI, R.O., RESENDE, D.C., ESPÍRITO-SANTO, H.M.V., BARROS, D.F. and PEREIRA, T.L., 2004. Alien fishes in lakes of the Doce river basin (Brazil): range, new occurrences and conservation of native communities. Lundiana, vol. 5, no. 2, pp. 135-142.

LOWE-MCCONNELL, R.H., 1999. Estudos ecológicos de comunidades de peixes tropicais. São Paulo: EDUSP.

MAIA-BARBOSA, P.M., BARBOSA, L.G., BRITO, S.L., GARCIA, F., BARROS, C.F.A., SOUZA, M.B.G., MELLO, N., GUIMARÃES, A.S. and BARBOSA, F.A.R., 2010. Limnological changes in Dom Helvécio Lake (South-East Brazil): natural and anthropogenic causes. Brazilian Journal of Biology $=$ Revista Brasileira de Biologia, vol. 70, no. 3, suppl., pp. 795-802. http:// dx.doi.org/10.1590/S1519-69842010000400010. PMid:21085784.

MAILLARD, P., PIVARI, M.O. and PIRES-LUIZ, C.H., 2012. Remote sensing for mapping and monitoring wetlands and small lakes in Southeast Brazil. In: Y. CHEMIN, ed. Remote sensing of planet earth. Rijeka: InTech. pp. 23-46.

MOL, J.H., 1996. Reproductive seasonality and nest-site differentiation in three closely related armoured catfishes (Siluriformes: Callichthyidae). Environmental Biology of Fishes, vol. 45, no. 4, pp. 363-381. http://dx.doi.org/10.1007/BF00002529.
PELICICE, F.M., VITULE, J.R.S., LIMA-JUNIOR, D.P., ORSI, M.L. and AGOSTINHO, A.A., 2013. A serious new threat to Brazilian freshwater ecosystems: the naturalization of non- native fish by decree. Conservation Letters, vol. 7, no. 1, pp. 55-60. http://dx.doi.org/10.1111/conl.12029.

PEIXOTO, R.S., BRANDÃO, L.P.M., VALADARES, C.F. and BARBOSA, P.M.M., 2010. Occurrence of Kellicottia bostoniensis (Rousselet, 1908) and Mesocyclops ogunnus Onabamiro, 1957 in lakes of the Middle River Doce, MG, Brazil. Acta Limnologica Brasiliensia, vol. 22, no. 3, pp. 356-360. http://dx.doi.org/10.1590/ S2179-975X2010000300012.

PINTO-COELHO, R.M., BEZERRA-NETO, J.F., MIRANDA, F., MOTA, T.G., RESCK, R., SANTOS, A.M., MAIA-BARBOSA, P.M., MELLO, N.A.S.T., MARQUES, M.M., CAMPOS, M.O. and BARBOSA, F.A., 2008. The inverted cascade in tropical plankton communities: impacts of exotic fish in Middle Rio Doce lake district, Minas Gerais, Brazil. Brazilian Journal of Biology = Revista Brasileira de Biologia, vol. 68, no. 4, suppl., pp. 10251037. http://dx.doi.org/10.1590/S1519-69842008000500010. PMid:19197473.

POMPEU, O.S. and GODINHO, A.L., 2001. Mudança na dieta da traíra Hoplias malabaricus (Bloch) (Erythrinidae, Characiformes) em lagoas da bacia do rio Doce devido à introdução de peixes piscívoros. Revista Brasileira de Zoologia, vol. 18, no. 4, pp. 1219-1225. http://dx.doi.org/10.1590/S0101-81752001000400016.

REIS, R., 1998. Anatomy and phylogenetic analysis of the Neotropical callichthyid catfishes (Ostariophysi, Siluriformes). Zoological Journal of the Linnean Society, vol. 124, no. 2, pp. 105-198. http://dx.doi.org/10.1111/j.1096-3642.1998.tb00571.x.

REIS, R.E., 2003. Family Callichthyidae (Armored catfishes). In: R.E. REIS, S.O. KULLANDER and C.J. FERRARIS-JUNIOR, eds. Check list of the freshwater fishes of South and Central America. Porto Alegre: EDIPUCRS. pp. 291-309.

RICCIARDI, A. and MACISAAC, H.J., 2011. Impacts of biological invasions on freshwater ecosystems. In: D.M. RICHARDSON, ed. Fifty years of invasion ecology: the legacy of Charles Elton. Oxford: Blackwell Publishing. pp. 211-224.

SALAS, H.J. and MARTINO, P., 1991. A simplified phosphorus trophic state model for warm-water tropical lakes. Water Research, vol. 25, no. 3, pp. 341-350. http://dx.doi.org/10.1016/00431354(91)90015-I.

SANTOS, T.R.M., 2008 [viewed 17 June 2013]. A influência de espécies introduzidas de peixes nas interações tróficas da ictiofauna da lagoa Carioca, Parque Estadual do Rio Doce, MG [online]. Belo Horizonte: Universidade Federal de Minas Gerais, 135 p. Masters Dissertation in Ecology, Conservation and Management of Wildlife. Available from: http://www.icb.ufmg.br/pgecologia/ dissertacoes/D205_Thiago_Russell_Miguel_Santos.pdf

SPEZIALE, K.L., LAMBERTUCCI, S.A., CARRETE, M. and TELLA, J.L., 2012. Dealing with non-native species: what makes the difference in South America? Biological Invasions, vol. 14, no. 8, pp. 1609-1621. http://dx.doi.org/10.1007/s10530-011-0162-0.

SUNAGA, T. and VERANI, J.R., 1991. The fish communities of the lakes in Rio Doce Valley, Northeast Brazil. Verhandlungen - Internationale Vereinigung für Theoretische und Angewandte Limnologie, vol. 24, no. 4, pp. 2563-2566.

VASCONCELLOS, M.G., ASSUMPÇÃO, A.M., SOARES, A.S., LUCCA, J.V., VERANI, J.R., FENERICH-VERANI, N. and ROCHA, O., 2005. Análise da diversidade de espécies de peixes em 4 lagoas do Sistema de Lagos do Vale do Médio Rio 
Doce - MG, em relação à ocorrência de espécies exóticas. In: O. ROCHA, E.L.G. ESPÍNDOLA, N. FENERICH-VERANI, J.R. VERANI and A.C. RIETZLER, eds. Espécies invasoras em águas doces: estudos de caso e propostas de manejo. São Carlos: EDUFSCar. pp. 119-129.

VIEIRA, F., 1994 [viewed 12 April 2013]. Estrutura de comunidade e aspectos da alimentação e reprodução dos peixes em dois lagos do médio Rio Doce. Belo Horizonte: Universidade Federal de Minas Gerais, 87 p. Masters Dissertation in Ecology, Conservation and Management of Wildlife. Available from: http://www.icb.ufmg. br/pgecologia/dissertacoes/D019_Fabio_Vieira.pdf

VIEIRA, F., 2009-2010. Distribuição, impactos ambientais e conservação da fauna de peixes da bacia do rio Doce. $M G$. Biota, vol. 2 , no. 5 , pp. $5-22$.
VITULE, J.R.S., FREIRE, C.A. and SIMBERLOFF, D., 2009. Introduction of non-native can certainly be bad. Fish and Fisheries, vol. 10, no. 1, pp. 98-108. http://dx.doi.org/10.1111/j.14672979.2008.00312.x.

VITULE, J.R. and PRODOCIMO, V., 2012. Introdução de espécies não nativas e invasões biológicas. Estudos de Biologia: Ambiente e Diversidade, vol. 34, no. 83, pp. 225-237. http:// dx.doi.org/10.7213/estud.biol.7335.

ZARET, T.M. and PAINE, R.T., 1973. Species Introduction in a Tropical Lake: a newly introduced piscivore can produce population changes in a wide range of trophic levels. Science, vol. 182, no. 4111, pp. 449-455. http://dx.doi.org/10.1126/ science.182.4111.449. PMid:17832455. 